\title{
円管内振動流の滑面摩擦抵抗則 \\ FRICTIONAL RESISTANCE LAW FOR AN OSCILLATORY PIPE FLOW WITH SMOOTH BOUNDARIES
}

\author{
沢 本 正 樹* -日 野 幹 雄** \\ By Masaki SAWAMOTO and Mikio HINO
}

\section{1.はじめに}

振動流の壁面抵抗則は，流れが全サイクルにわたって 層流の場合には, 境界層流れであっても, 円管流であっ ても純解析的に求められる，層流理論の妥当性は，壁面 抵抗に限らず, 各種の物理量について理論と実験との合 致が確かめられており，問題はない( ${ }^{5,99,13)}$. その適用限 界は, Stokes のパラメータ入が, 1.5 以上に対して, $R_{\delta}$ $<550,1.5$ 以下に対して, 大体, $R_{e}<2100$ である11,2). ここに $R_{\delta}, R_{e}$ は, それぞれ, 振動流境界層厚さのパラ メータ $\delta=\sqrt{\frac{2 \nu}{\omega}}$, および, 管径 $d$ を用いて定義した Reynolds 数 $R_{\delta}=\frac{\hat{U} \delta}{\nu}, R_{e}=\frac{\hat{U} d}{\nu}$ であり, $\lambda$ は $\delta$ と管 の半径の比 $\lambda=\frac{d}{2} / \delta, \omega$ は振動の角周波数, $\hat{U}$ は断面平 均流速の振幅である注).

波, または, 潮流による振動乱流境界層の抵抗則を理 論的に解析したものは, Kajiura $(1964,1968)^{3), 4)}$ が 最初であろう. 彼のモデルは, 振動の全サイクルにわた って乱流が 続くと仮定し, 渦動粘性係数 $K_{z}$ を導入し て, 問題を抎散方程式に帰着させ, 解析を行うものであ る. 渦動粘性係数の分布は, Kármán 定数などの定常乱 流境界層での知識からの直接的類推により滑面, 粗面, そ れぞれの場合について仮定されている. 結果は, たとえ ば, 滑面上の振動流境界層に対する Riedel, Kamphuis and Brebner (1972) ${ }^{5)}$ による抵抗係数の実測との差は 2 割程度であり, $R_{\delta}$ による変化の傾向はよく一致して

\footnotetext{
* 正会員 工博 東京工業大学助手 土木工学科

** 正会員 工博 東京工業大学教授 土木工学科

注）文献 1)においては， $\lambda$ を $\frac{d}{\sqrt{2}} / \delta$ と定義しているが，そ

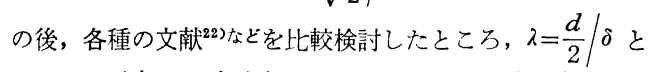
したものが多く，本論文では，それらとの関連を容易にす るために, この定義 $\lambda=\frac{d}{2} / \delta$ を用いる.なお, 著者らの他 の文献，2，19）は，この新しい定義を使用している.
}

いる.また, Jonsson $(1963)^{6)}$ による粗度上の振動流の 測定結果とも, 壁面の極く近傍を除き, よく一致してい る.

このように渦動粘性係数の分布を仮定して, 振動流の 流れの場を解析したものに, 波動境界層を対象とした Johns $(1968)^{7)}$, 野田 $(1969)^{8)}$, 円管流を対象とした安 川・田川(1972) ${ }^{9)}$ がある.

この種のモデルの合一不合理性は, いつに, 渦動粘性 係数の仮定が適切であるか否かにかかっている. 実際に は, 次のようなモデルの不備が実験的に認められてい る. すなわち, 渦動粘性係数が時間とともに大きく変動 する一堀川・渡辺 $(1968)^{10)}$, 堀川・水口 $(1973)^{11)}$, 定 数と仮定したものが, Reynolds 数の関数にしないと現 象をうまく説明できない一安川・田川 $(1972)^{9)}$ ，流れは 全位相を通じての乱流にはならない一日野・沢本・高須 $(1975)^{1)}$ ，などのことが確認されている.しかし，振動 流についての実験的な把握が十分なされていない時期に 発表されたことを考えると，Kajiura のモデルの提案 は,きわめて意義深い.

振動流境界層の壁面抵抗を, 直接 shear plate を用い て測定することは, 層流一乱流にわたり試みられてい る. Eagleson $(1962)^{12)}$, 岩垣・土屋・坂井 $(1964)^{13)}$, 松梨・川谷 $(1965)^{14)}$ は, 層流域で, Riedel, Kamphuis and Brebner (1972) ${ }^{5)}$ は，粗面-滑面，層流-乱流にわ たり測定を行っている. 特に Riedel らの結果はきわめ て系統的で, かつ精度も高いように思われ，その価值は 高い,この結果を用いれば, 振動流境界層については, 壁面抵抗の推算が可能である.

一方, 円管流については, 系統的な実験結果は報告さ れておらず，また，使い易い形での抵抗則の提案もなさ れていない.

管路で, 工学的に振動流現象が問題となるものに, 水 撃圧, およびサージングの問題がある. 水撃圧が問題と なる管路系の設計にあたっては, 一般には圧力波の伝播 および最大圧力上昇に関心の重点がおかれ, 摩擦損失を 
無視した 計算が行われている ${ }^{15), 16)}$. これは 最大圧力上 昇が最も重要な問題であることとともに，摩擦を考慮し た波動方程式が繁雑となることも大きな理由の一つであ $る^{17)}$ ．そのため，摩擦損失をどのように計算に組み込む かとか, 損失係数をいくらにするのが適当かなどの点に 対し, 信頼しうる方法は確立されていない. そして, 水 撃圧の減衰を問題としなければならない場合には，(i) 基本方程式に摩擦力の効果をいれずに，近似的に境界条 件が減衰効果をもつように修正する17) とか，(ii）定常流 での抵抗則を準用するとかの方法がとられる.しかし， （i）の方法はいかにも便宜的で一般性に欠け，(ii）の方 法ではしばしば実測とかけ離れた隇衰が計算される— 荻原 $(1973)^{18)}$ など.

サージングの場合, 液体振動の減衰は重要な関心事で ある.この場合には, 水撃圧の周期が数秒であるのに対 し, 周期が数分と現象の時間スケールが長いため, 定常 流の抵抗則を準用している.すなわち，設計にあたって は, 定常流での Manning の $n$ の值を用いている ${ }^{15)}$. しかし，これにも問題がないわけではない。現象の時間 スケールが長い場合には，確かに定常円管流での抵抗則 を使えるわけであるが，では時間が長いとか短いという のは，いったいどの程度のことをいうのであろうか．振 動流に対して準定常性がいえるためには，流れの構造が， 定常流のそれとよく似ていることが必要である. 著者ら の実験1によれば，流れは Stokes のパラメータれが， 1.5 以上では, 乱れのあらわれ方, 流速分布などの面で すでに明瞭な非定常の特性を示している.この $\lambda>1.5$ という限界は周期になおすと $T>\frac{\pi d^{2}}{4} \frac{1}{\nu \lambda^{2}}$ であるか ら，水を例治ってみると，径 $1 \mathrm{~cm}, 10 \mathrm{~cm}, 50 \mathrm{~cm}$ の 円管に対し，それぞれ，周期が $35 \mathrm{sec}, 1$ 時間, 1 日以上 に対応する.すなわち, われわれが直感的に考えている よりも，はるかに長い周期にまで非定常性の考慮が必要 となる.さらに，振動流に定常流の考え方を適用するこ とは, 上述のように定常乱流と非定常乱流の構造の違い を無視することになるばかりでなく，非定常流の乱流遷 移が，管径 $d$ を用いて定義した Reynolds 数 $R_{e}$ で説 明できず, $R_{e}$ が 2100 を越えた相当高い值ででも層流 状態が成立する1) ため, ややもすると，層流を乱流とし て取り扱らといら過誤をひき起こしやすいといった難点 をも内含している.

本研究では, まず層流抵抗則について説明した後で淮 定常の仮定からどのような抵抗則が得られるかを示し， 次に著者らの振動流に関寸る実験 ${ }^{1), 19)}$ 加ら得られた知識 をもとに指数型の抵抗則を提案する.

さらに，振動流の簡単なモデルとして，U字管内の液 柱の振動の問題をとりあげ, その減衰性を解析する. 解 析結果は, 安川・田川 $(1972)^{9)}$ の実験結果と比較され,
提案した抵抗則が妥当であることが検証される。

\section{2. 層流抵抗則}

円管内振動流の層流抵抗則は, 純解析的に 求められ る. その解法は文献 1)，9）などに示されている. 結果 は次の通りである。

$$
\left.\begin{array}{l}
U(r, t)=\operatorname{Real}\left\{\hat{U} V_{c}\right\} \\
V_{c}=-\frac{J_{0}\left(\beta_{0} \eta\right)-J_{0}\left(\beta_{0}\right)}{J_{0}\left(\beta_{0}\right)+\frac{1+i}{\lambda} J_{1}\left(\beta_{0}\right)} e^{i \omega t} \\
\beta_{0}=\sqrt{2} \lambda e^{\frac{3}{4} \pi i}, \eta=r / \frac{d}{2}
\end{array}\right\}
$$

ここに, $U$ は管軸方向の流速, $\hat{U}$ は断面平均流速 $U_{m}$ の振幅, すなわち,

$$
U_{m}=\frac{4}{\pi d^{2}} \int_{0}^{d / 2} U 2 \pi r d r=\operatorname{Real}\left\{\hat{U} e^{i \omega t}\right\}
$$

$r$ は半径方向の距離, $J_{0}, J_{1}$ は Bessel 関数である. 式 （1）を用いれば, 壁面せん断応力は容易に求められる9). ここでは，文献 9）と異なり次のような抵抗倸数を用い た形で抵抗則を表わすことにする. 式 (1) より複素壁 面せん断応力 $\tau_{c}$ ，および複素壁面抵抗係数 $f_{c}$ は，それ ぞれ，

$$
\begin{gathered}
\tau_{c}=\left.2 \rho \frac{\hat{U}^{2}}{R_{e}} \frac{\partial V_{c}}{\partial \eta}\right|_{\eta=1} \\
f_{c}=-\frac{8}{\hat{U}^{2} e^{i \omega t}} \frac{\tau_{c}}{\rho}
\end{gathered}
$$

となる.ここに, せん断応力は管央部を加速する方向に 正と定義してある. 実際の壁面せん断応力は $\tau_{c}$ の実 部

$$
\tau_{w}=\left.\mu \frac{\partial U}{\partial r}\right|_{r=d / 2}=\left.2 \rho \frac{\hat{U}^{2}}{R_{e}} \frac{\partial\{\operatorname{Real} l}{\partial \eta} \frac{\left.V_{c}\right\}}{{ }^{\prime}}\right|_{\eta=1}
$$

である.ここで, 振動流の壁面抵抗係数 $f$ を

$$
f \equiv \frac{8}{\hat{U}^{2}} \max \left(\frac{\tau_{w}}{\rho}\right) \text {.......... }
$$

と定義すると, $f$ は $f_{c}$ の絶対値と等しくなる. 一方, $f_{c}$ の偏角 $\theta$ 澼面せん断応力 $\tau_{w}$ と平均流速 $U_{m}$ の 位相差を表わしている.

式 (1) より $f_{c}$ を求めると, その絶対值 $f$ につて は,

$$
f=\frac{C_{e}(\lambda)}{R_{e}}=\frac{C_{\delta}(\lambda)}{R_{\delta}}
$$

といら関係が得られる.ここに $C_{e}(\lambda), C_{\delta}(\lambda)$ は比例定 数で $\lambda$ のみの関数である. また, 偏角 $\theta$ は $\lambda$ のみの関 数として得られる.

$C_{e}(\lambda), C_{\delta}(\lambda)$ および $f_{c}$ の偏角 $\theta(\lambda)$ は, 図一1 に示 されている．この結果を用いると，層流時の壁面せん断 応力は, 式 (4), および 


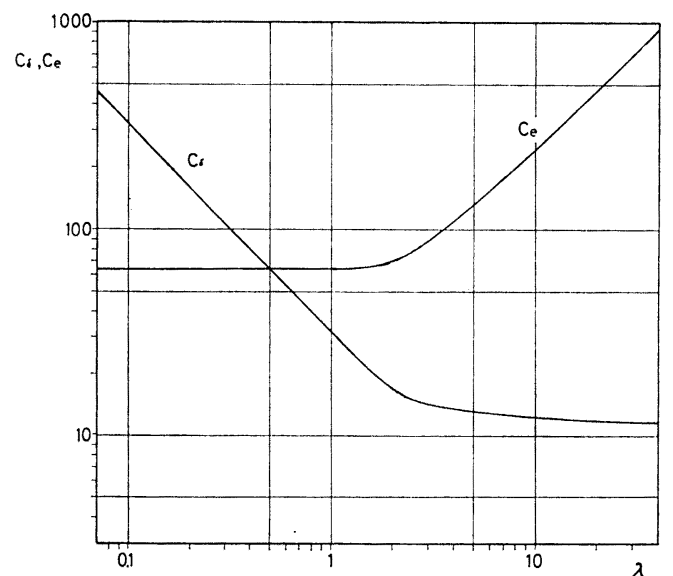

(a) $C_{e}, C_{\delta} \sim \lambda$

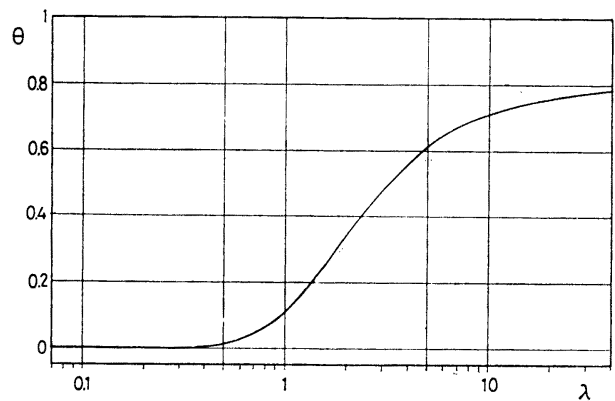

(b) $\theta \sim \lambda$

図-1

$$
\frac{\tau_{w}}{\rho}=-\frac{f}{8} \hat{U} U_{m}\left(t+\frac{\theta}{\omega}\right)
$$

より計算することができる.

図一1 によると $\lambda \rightarrow 0$ では $C_{\boldsymbol{e}} \rightarrow 64, \theta \rightarrow 0$ となり,

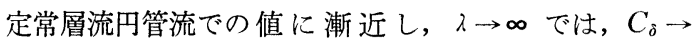
$11.3, \theta=\frac{\pi}{4}$ となり, 振動層流境界層, いわゆる, Stokes 流れでの抵抗則に 漸近する. すなわち, 層流の 場合, $\lambda<1$ では, 定常円管流近似が成り立ち, $\lambda>10$ では, 振動層流境界層近似が成り立つ.

この層流抵抗則の 適用範囲は, Stokes のパラメータ $\lambda$ が 1.5 以上では， $R_{\delta}<550$ である ${ }^{1), 2)} . \lambda$ が $0 \sim 1.5$ では遷移限界は明確ではないが， $R_{e}<2100$ としてお けば間違いはない。

\section{3. 滑面乱流抵抗則}

\section{（1）準定常理論}

定常円管流の抵抗係数と Reynolds 数 $R_{e}=\frac{U_{m} d}{\nu}$ と の関係は Moody 図表としてよく知られている. 非常に 周期の長い ( $\lambda$ が小さい) 流れには, この図表が適用し らることが容易に推測できる。ではこの図表は一般的な
振動流にも適用しうるのであろうか.

振動流の抵抗係数 $f$ を式 (3) で定義すると, 定常流 の抵抗則は， $\frac{\tau}{\rho}, U_{m}$ をそれぞれ, 振動流の場合の振幅 に置き換えるだけで，見かけ上振動流の抵抗則に挔張で きる．これを著者らの実験条件 $\lambda=3.62^{19)}$ ，および，安 川・田川 $(1972)^{9)}$ の実験条件に適用したところ，前者で は約 2 倍, 後者では約 1.5 倍実測值より大きい抵抗係数 を与えることとなった．また，定常流での滑面抵抗則の 一つである Blasius の経験則に対応する流速分布形 $1 / 7$ 乗則は， $\lambda=1.91$ ではすでに成り立たないことが確かめ られている ${ }^{19)}$.さらに，遷移 Reynolds 数に関しては， $\lambda>1.5$ では管径を用いて定義した Reynolds 数 $R_{e}$ よ

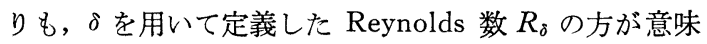
があり，非定常の効果が大きいことがわかっている(1),2). 以上のことから, 少なくとも, $\lambda>1.5$ 以上の流れに対 しては, Moody 図表に基づく壁面せん断応力の算定は 不適であると結論できる.

非定常性が大きい場合に 重要な意味をもつ Reynolds 数 $R_{\delta}$ の物理的な意味を考えてみよう. いま, 平均流速 $U_{m}$ が時間に関し正弦的に変化する流れ

$$
U_{m}=\hat{U} \sin \omega t
$$

を考える.この時 $R_{\delta}$ は

$$
R_{\delta}=\frac{\hat{U} \delta}{\nu}=\left\{\frac{2 \hat{U}^{2}}{\nu \omega}\right\}^{1 / 2}
$$

となる.ささてここで $R_{\delta}$ のほかに流体粒子の転流時か らの移動距離 $x$ と, 各時刻に扔りる平均流速 $U_{m}$ とで 定義した Reynolds 数 $R_{x}$ を考えてみる. $x$ は

$$
x=\int_{0}^{t} U_{m} d t=\frac{\hat{U}}{\omega}(1-\cos \omega t)
$$

であるから， $R_{x}$ は

$$
R_{x}=\frac{U_{m} x}{\nu}=\frac{\hat{U}^{2}}{\nu \omega}(\sin \omega t-\sin \omega t \cos \omega t)
$$

となる.これと式 $(6)$ とから $R_{x}$ と $R_{\delta}$ は

$$
R_{x}=0.5 R_{\delta}^{2} \sin \omega t(1-\cos \omega t)
$$

のように関係ゔけられる. すなわち， $R_{\delta}$ は流体粒子の 移動距離を用いて定義した Reynolds 数 $R_{x}$ の最大値 と表裏一体の関係にあることがわかる.このことは, 次 のことからもらなずける. $R_{x}$ の最大值は，

$$
\left\{R_{x}\right\}_{\text {max }}=0.649 R_{\delta}{ }^{2}
$$

となる. 振動流の限界 Reynolds 数 $R_{\delta}=550$ をこれに 代入すると

$$
\left\{R_{x}\right\}_{\text {max }} \fallingdotseq 2 \times 10^{5}
$$

が得られる. これは, 定常円管流の入口での限界 Reynolds 数とほぼ一致している20). すなわち, パラメータ として $R_{\delta}$ を用いることは, 流れの履歷を流体粒子の移 動距離 $x$ を介して考慮したことに対応している.

さて, 定常流においては流体粒子の移動距離で定義し 
た Reynolds 数で決定されるような流れには平板上の 境界層流れがあげられる。ここでは，振動流の流れを平 板境界層に近似させて抵抗則を推算する方法を考える. このような近似はもちろん物理的に悠密なものではな い.しかし，振動流においても，入のある範囲では, 転 流時以降，流体粒子の流下とともに，壁面から境界層が 発達していく流れとなっており，しかも，振動流におけ る乱流構造の知識の不足から, 流れを厳密汇計算するこ とが不可能であることを考えると，このような流れをま ず定常流境界層で近似してみることも，意味のないこと ではない. 以下具体的に説明する.

定常流平板境界層では壁面せん断応力 $\tau_{w}$ は, 抵抗係 数 $c_{f}$ と, 境界層外縁での流速 $U_{0}$ を用いて,

$$
\tau_{w}=-c_{f} \rho U_{0}^{2} / 2
$$

で与えられる. $c_{f}$ と $R_{x}=\frac{U_{0} x}{\nu}(x$ は平板前端からの 距離）との関係は, Kármán, Schultz-Grunow などの 式や，図表で与えられている.ここでは，一例として扱 い易さから滑面に対する次の 式望を用いて議論を進める.

$$
\left.\begin{array}{l}
c_{f}=0.059 R_{x}{ }^{-1 / 5} \\
R_{x}<10^{7}
\end{array}\right\} \cdots(9)
$$

式（8）および（9）の関係が $U_{0}$ を平均流速 $U_{m}$ に置き換え るだけで,そのまま振動流にも 適用しらると仮定する. 代表流 速として管軸での流速ではなく 平均流速を用いることは，大い に問題の残る点ではあるが,こ こでは振動流についての実験的 に得られる定数に頼らずに定常 流からの類推だけでどの程度の ことがいえるのかを確かめるこ とを目的とし，ある程度の誤差 を容認した上でこの方法を採用 する.

以上より，各時刻における壁 面せん断応力を計算寸ると, $0 \leq \omega t \leq \pi$ では

$$
\begin{aligned}
\frac{\tau_{w}}{\rho}= & -\frac{1}{8} \hat{U}^{2} 4 c_{f} \sin ^{2} \omega t \\
= & -\frac{1}{8} \hat{U}^{2} \cdot 0.271 R_{\tilde{o}}^{-2 / 5} \\
& \cdot \frac{(\sin \omega t)^{1.8}}{(1-\cos \omega t)^{0.2}} \cdots(10)
\end{aligned}
$$

となる. $\frac{(\sin \omega t)^{1.8}}{(1-\cos \omega t)^{0.2}}$ は図 -2 に示すような $\sin \omega t$ をゆ がめたような関数である. $\pi \leq \omega t \leq 2 \pi$ では, 符号が逆，才なわち逆方向の応力と して同じような時間変化を繰り返す.この方法の適用限 界は乱流でかつ式 (9) の適用しらる範囲であるから， $R_{\delta}$ で表わすと

$$
550<R_{\hat{o}}<\quad 4500
$$

限界 Reynolds 数 式 (9) の適用限界

である.

式（10）は時間に関しては複雑な形をしており，必ず しも使い易いとはいい難い，実際に応用するにあたって は, 式 (10) の時間変動をさらに正弦関数で近似しなお し, かつ式 (3) で定義した抵抗係数 $f$ を用いて,

$$
\begin{aligned}
& f=0.271 R_{\delta}^{-2 / 5}=0.358 \lambda^{2 / 5} R_{e}-2 / 5 \\
& \frac{\tau_{w}}{\rho}=-\frac{1}{8} f \hat{U} U_{m}
\end{aligned}
$$

の形で使用することも一つの便法であろう.

以上, 滑面に対する $c_{f}$ から振動流の $f$ を求める方 法を述べたが，同様の考え方は粗面に対しても可能であ ることはいらまでもない。
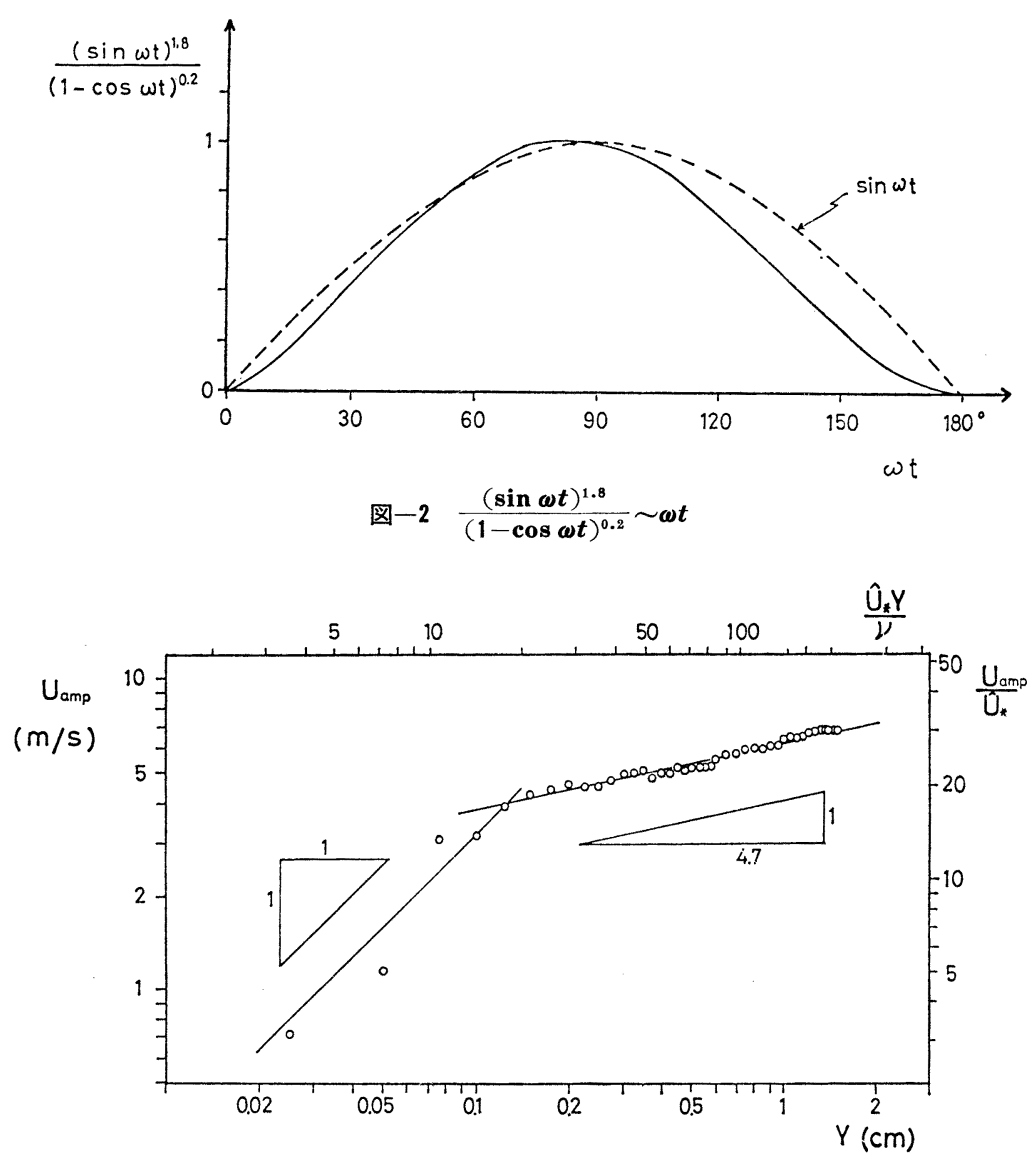

RUN 31

$\lambda=3.62$

$\hat{R}_{\delta}=1360$ 


\section{（2）指数型抵抗則}

定常流では，流速分布に関する $\frac{1}{7}$ 乗則は滑面抵抗係 数 $f$ に対する Blasius の経験則と結びついている. 振 動流においても，流速分布の指数則が確認できれば, 同 様の演絼で指数型の抵抗則が得られる. 著者の一人は, 文献 19)で, 熱線流速計を用い空気振動流の詳細な流速 分布測定の結果を報告している.それによると, Stokes のパラメータ $\lambda=3.62$ の流れでは, (i) 減速時の乱れの 激しい位相に扔いて, 明瞭な粘性底層の存在が認められ る，(ii）粘性底層内の速度勾配より壁面せん断応力を求 めると, それは時間に関し正弦的に変化し，かつ平均流 速と同位相である，かつ同じデータを用いて流速の指数 分布を調べてみると，（iii）図一3に示すように，粘性 底層の外側では, 壁面からの距離 $y$ の $\frac{1}{4.7}$ 乗に比例す る速度分布が存在するなどのことが確かめられた.

これらの事実から振動流の抵抗係数 $f$ を求めてみよ う. 各点での流速の振幅 $U_{\mathrm{amp}}$ の分布は, 次のように 書き表わすことができる.

$$
\left.\begin{array}{l}
\frac{U_{\mathrm{amp}}}{\hat{U}}=c_{0}\left(\frac{y}{\frac{d}{2}}\right)^{1 / n} \\
c_{0}=\frac{1}{2} \frac{(2 n+1)(n+1)}{n^{2}}
\end{array}\right\}
$$

ここに, $y$ は壁面からの距離, $c_{0}$ は管軸での流速と平 均流速の比をあらわす定数であり, $n=4.7$ の場合, 1.342 となる. 粘性底層を考虑すると, $c_{0}$ の值は多少変 わるが，その差は小さい. 図一3 の測定結果では式 (13) は $\hat{U}_{*}$ で無次元化すると，

$$
\frac{U_{\mathrm{amp}}}{\hat{U}_{*}}=9.89\left(\frac{\hat{U}_{*} y}{\nu}\right)^{1 / 4.7}
$$

とも書き表わすことができる.ここに $\hat{U}_{*}$ は

$$
\hat{U}_{*}=\sqrt{\left.\nu \frac{d U_{\mathrm{amp}}}{d y}\right|_{y=0}}
$$

で定義された摩擦速度であり, 粘性底層内での流速測定 結果より計算される.

式 (13),(14)に $y=\delta$ を代入し，ンとして 3.62 を用 いて $\hat{U}_{*}$ について解くと

$$
\hat{U}_{*}=0.1533 R_{\delta}{ }^{-1 / 5.7} \hat{U}
$$

が得られる. - $\frac{\tau_{w}}{\rho}$ の極大值は $\hat{U}_{*}{ }^{2}$ であるから, 式 (3) で定義した抵抗係数 $f$ は

$$
\begin{aligned}
f & =8 \frac{\hat{U}_{*^{2}}}{\hat{\theta}^{2}}=0.188 R_{\delta}^{-1 / 2.85} \\
& =0.240 \lambda^{1 / 2.85} R_{e}^{-1 / 2.85} \ldots . .
\end{aligned}
$$

$$
\frac{\tau_{w}}{\rho}=-\frac{1}{8} f \hat{U} U_{m}
$$

で計算できる.この抵抗則の適用範囲については 5. で 考察する.

\section{U 字管振動}

図一4 に示すようなU字管内の液柱振動は，振動流の 簡単なモデルとしてしばしば解析が行われている。ここ では前章で提案した抵抗則を用いて，このような流体運 動の減衰性を調べる.

U字管振動の運動方程式は, 摩擦損失に比べて曲りに よる損失などが無視できるとすると，

$$
\rho \frac{\pi d^{2}}{4} l \frac{d^{2} \xi}{d t^{2}}=\tau_{w} \pi d l-2 \xi \rho g \frac{\pi d^{2}}{4}
$$

と表わされる.ここに， $\xi, l$ は，それぞれ液柱の変位お よび長さである. 両辺を $\rho \frac{\pi d^{2}}{4} l$ でわると，

$$
\begin{aligned}
& \frac{d^{2} \xi}{d t^{2}}-\frac{4}{d} \frac{\tau_{m}}{\rho}+\omega_{0}{ }^{2} \xi=0 \\
& \omega_{0}{ }^{2}=2 g / l
\end{aligned}
$$

となる. 式 (17) の解は減衰振動となる.これに前章ま での振動流抵抗則を適用し, 層流, 乱流, それぞれの場 合の減衰性を求める.

\section{a) 層流}

層流の場合の 減衰振動は安川・田川 $(1972)^{9)}$ 亿も示 されて抢り，ここではその結果のみを示す.

減衰振動を

$$
\xi=\xi_{i} e^{\beta\left(t-t_{i}\right)} \cos \omega\left(t-t_{i}\right)
$$

と表わすと， $\omega, \beta$ は次のようになる.

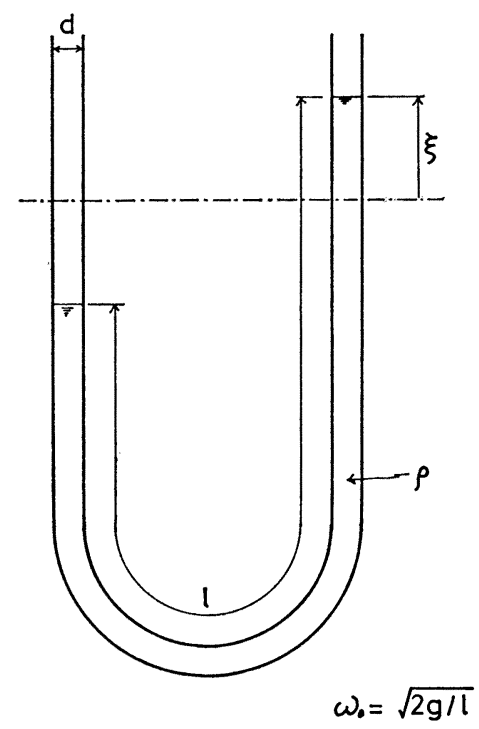

図-4U 字管 振 動 


$$
\begin{aligned}
& \frac{\omega}{\omega_{0}}=\frac{1}{\sqrt{1+\frac{C_{\delta}}{8 \lambda} \sin \theta+\frac{\left(\frac{C_{\delta}}{8 \lambda}\right)^{2} \cos ^{2} \theta}{2+\frac{C_{\delta}}{8 \lambda} \sin \theta}-\left(\frac{\frac{C_{\delta}}{8 \lambda} \cos \theta}{2+\frac{C_{\delta}}{8 \lambda} \sin \theta}\right)^{2}}} \\
& \frac{\beta}{\omega_{0}}=\frac{-\frac{\frac{C_{\delta}}{8 \lambda} \cos \theta}{2+\frac{C_{\delta}}{8 \lambda} \sin \theta}}{\sqrt{1+\frac{C_{\delta}}{8 \lambda} \sin \theta+\frac{\left(\frac{C_{\delta}}{8 \lambda}\right)^{2} \cos ^{2} \theta}{2+\frac{C_{\delta}}{8 \lambda} \sin \theta}-\left(\frac{\frac{C_{\delta}}{8 \lambda} \cos \theta}{2+\frac{C_{\delta}}{8 \lambda} \sin \theta}\right)^{2}}}
\end{aligned}
$$

は式(18)の形の解を持ち， $\omega, \beta$ はそれぞれ，

$$
\left.\begin{array}{c}
\frac{\omega}{\omega_{0}}=\frac{1}{\sqrt{1+\frac{1}{256}\left(\frac{f R_{\delta}}{\lambda}\right)^{2}}} \\
\frac{\beta}{\omega_{0}}=\frac{-\frac{1}{16} \frac{f R_{\delta}}{\lambda}}{\sqrt{1+\frac{1}{256}\left(\frac{f R_{\delta}}{\lambda}\right)^{2}}}
\end{array}\right\}
$$

となる、これより一周期間の減衰比は

$$
\frac{\xi_{i+1}}{\xi_{i}}=e^{\beta \frac{2 \pi}{\omega}}=\exp \left(-\frac{\pi}{8} \frac{f R_{\delta}}{\lambda}\right)
$$

(19) となる.

振動の一周期 $\frac{2 \pi}{\omega}$ の間の振幅の減衰比は, $\xi_{i+1} / \xi_{i}$ と畫 くと

$$
\frac{\xi_{i+1}}{\xi_{i}}=e^{\beta \frac{2 \pi}{\omega}}=\exp \left(-\frac{\frac{C_{\delta}}{8 \lambda} \cos \theta}{2+\frac{C_{\delta}}{8 \lambda} \sin \theta} 2 \pi\right)
$$

となる。

b）乱流

前章の抵抗則より，式（12）または式 (16) を式 (17) に代入すると，

$$
\frac{d^{2} \xi}{d t^{2}}+f \frac{R_{\delta}(\omega)}{8 \lambda} \frac{d \xi}{d t}+\omega_{0}^{2} \xi=0
$$

が得られる. 振動の一周期程度の時間では $R_{\dot{o}}$ は …定で あると仮定すると,式 (21) はよく知られた減衰振動の式 となり, その解は容易に求められる. 寸なわち, 式 (21)
抵抗係数 $f$ として式 (11), (15) を用いると， 定常境界層抵抗則による準定常理論では,

$$
\frac{\xi_{i+1}}{\xi_{i}}=\exp \left(-0.101 \frac{1}{\lambda} R_{\hat{\delta}}{ }^{3 / 5}\right)
$$

流速分布形に基づく指数型抵抗則では

$$
\frac{\xi_{i+1}}{\xi_{i}}=\exp \left(-0.0738 \frac{1}{\lambda} R_{\delta}^{1 / 1.54}\right)
$$

上なる。

参考のために，定常円管流でけ fを用いた場合の減 敦比を求めてみる上，層流では式 (23) と，

$$
f=\frac{54}{R_{e}}=\frac{32}{\lambda R_{o}}
$$

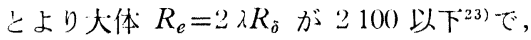

$$
\frac{\xi_{i+1}}{\xi_{i}}=\exp \left(-\frac{4 \pi}{\lambda^{2}}\right)
$$

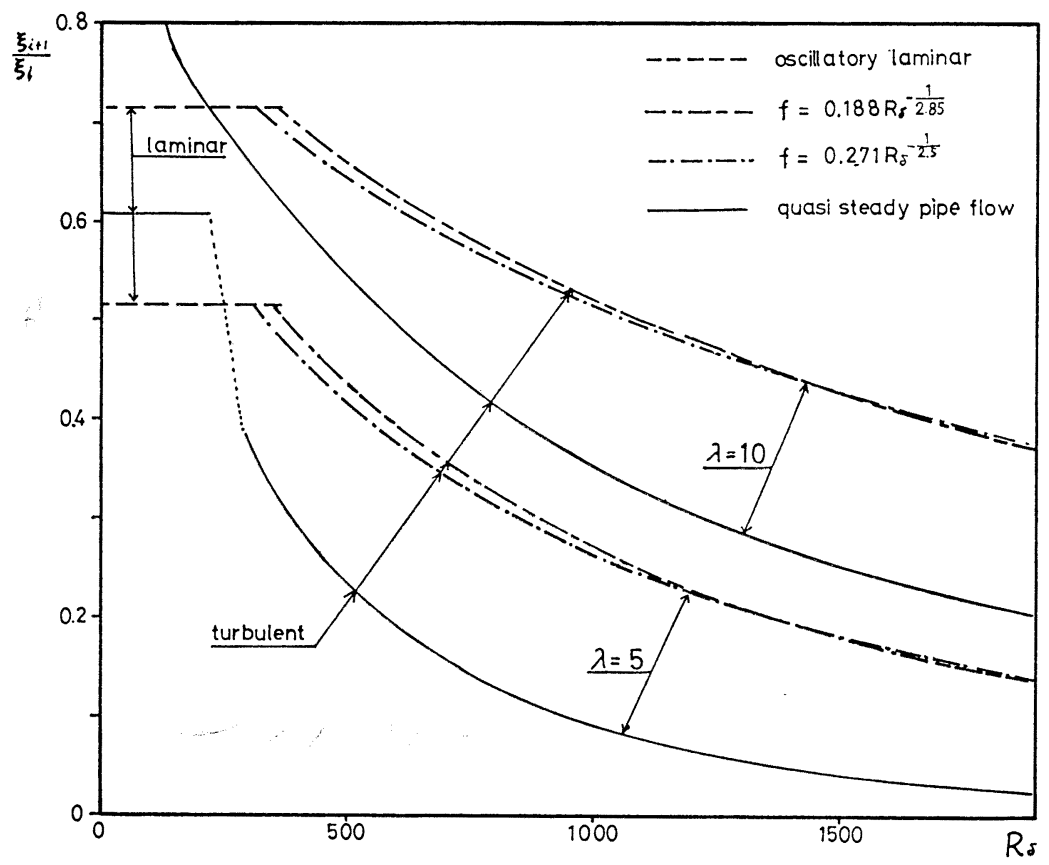

図一5U 字管振動の減衰比，各種抵抗則の比較 


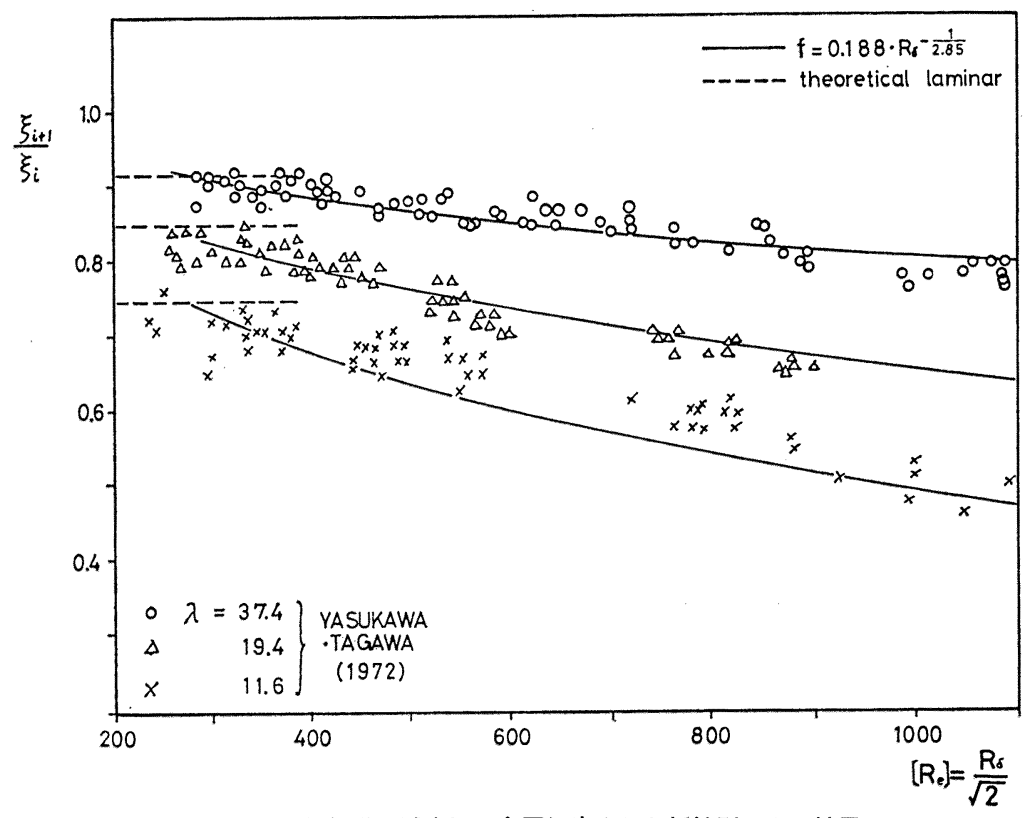

図一6U 字管振動の減衰比. 今回提案された抵抗則による結果と 安川・田川の実験結果との比較

乱流では, 式 (23) と Blasius の経験則

$$
f=0.316 R_{e}^{-1 / 4}=0.266 \lambda^{-1 / 4} R_{\delta}^{-1 / 4}
$$

とから, 大体 $R_{e}=2 \lambda R_{\delta}$ が 2900 以上年尚で,

$$
\frac{\xi_{i+1}}{\xi_{i}}=\exp \left(-0.104 \lambda^{-5 / 4} R_{\delta}^{3 / 4}\right)
$$

となる。

以上の計算例を 図一5 に示す. 図中, 実線は式 (26), （27）を表わし, 他の曲線は式 (20)，(24），(25）を表わ す.これによると, 提案された 2 つ抵抗則, 式 (11), （15）を用いた結果は，互いにきわめて近い值を与えて いる. 定常円管流での抵抗則を準用した場合の結果は, 振動流抵抗則を用いた 計算結果とは大きくはずれ， $R_{\delta}$ が小さいときは過小の減衰を， $R_{\delta}$ が大きい場合には， 過大の減衰を計算したことになっている.

安川・田川 $(1972)^{9)}$ は, U字管振動の 解析と実験を 行っている. 実験結果は減衰比の形で, Reynolds 数と 振幅のパラメータととで整理している. 彼らが定義した Reynolds 数 $\left[R_{e}\right]$ ととは, それぞれ, 次のように $R_{\delta}$ と入とに書き直すことができる.

$$
\left\lfloor R_{e}\right]=R_{\delta} / \sqrt{2}, r=\sqrt{2} \lambda
$$

この実験結果と上述の計算結果のうち, 指数型抵抗則の 結果とを比較したものを 図一6 に示してある.ここに 示してあるものは, $\lambda=37.4,19.4,11.6$ の 3 種である. 用いている抵抗則, 式 (15) は, もともと $\lambda=3.62$ の実 測の流速分布形から導いたものであり，入の他の值に対 しての適用性は何ら保証されていない. にもかかわらず ここに示した例では，3 種とも $\lambda$ が 3.62 とは大きくか
け離れているが，計算值と実測值との一致はよい。この ことは, 式 (15) の抵抗則が, 少なくとも $\lambda=37.4$ ま では適用しらることを示唆している.

\section{5. まと め}

前章までの抵抗則をまとめると次のようになる.

○層流の場合 式 (4),(5) および図一1

○乱流の場合 式 (16) と, 式 (11) または式 (15)

これらの結果は 図一7 に示されている. 図にはあわ せて,

○Riedel et al.(1972)の実験のうち滑面のもの, $\lambda=\infty$ ○Kajiura (1968) のモデルのうち滑面のもの, $\lambda=\infty$ ○著者らの実験, 滑面, $\lambda=3.62,3.90$ ものせてある.

層流抵抗則の適用範囲は $\lambda>1.5$ では $R_{\delta}<550^{1)}$, $\lambda<1.5$ では明確ではないが， $R_{e}<2100$ としておけ ば間違いはなさそうである.この抵抗則は理論的に厳密 に求められたものであり, スについての制限はない.

式 (11) の準定常近似は平板境界層の抵抗則を円管内 振動流に適用したものである.しかし，これを振動流境 界層 $\lambda \rightarrow \infty$ にそのまま適用するには難点がある. なぜ ならば，この近似は断面内での流速の位相差が無視しう るような状況の下で行われているからである. Jonsson $(1963)^{6)}$ の栈粗度上の流速測定では, 減速時に流れの位 相差があまり問題とならないのは, 壁から $\delta$ の 50 倍 程度の範囲までに拉いてである.よって,この近似が有 


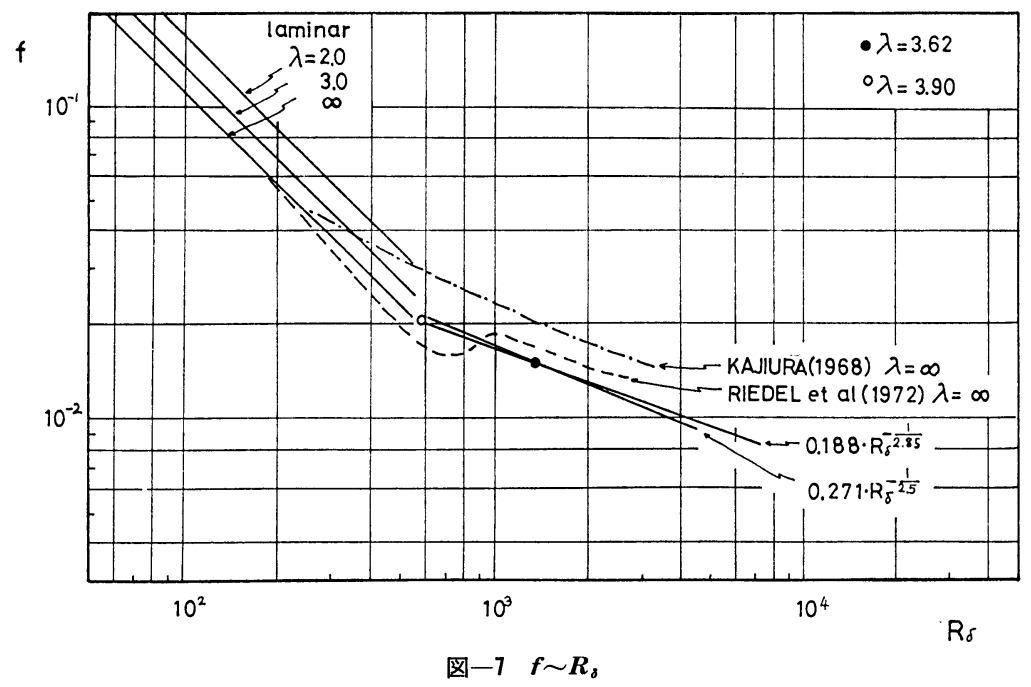

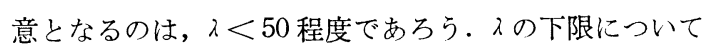
は確かな根拠はないが, 遷移実験 ${ }^{1}$ などから推察すると, $\lambda=1.5$ が一応の目安になる. $R_{\delta}$ についての制限は前述 の通りである.しかし，それは式（9）を採用した場合 のことであり，平板境界層の $c_{f} \sim R_{x}$ の図表を用いれ ば，より広い範囲の $R_{\delta}$ で\& $f \sim R_{\delta}$ の 関係を導くことは可能である。

式（11）の抵抗則はある程度の誤差を 容認する立場で導いたものであるが，結 果的には式 (15) と非常に近い值を与え る.このことは, 必ずしも式の誘導過程 が適切であったことを示すものではな く, むしろ, 準定常性の仮定が含むいく つかの誤差が互いに打ち消し合ったため と思われる。

式 (15) の抵抗則は, もともと $\lambda=$ 3.62 の実験結果から導かれたものであ る.よって, 本来適用範囲は $\lambda=3.62$ に 限られるはずである。しかし，図一6に 示したように， $\lambda=11.6,19.4,37.4$ に おいても精度よい結果を与えることが確 かめられた. また, 式 (15) と式 (11) はきわめて近い值を与えている.よっ て, 式 (15) の適用範囲は, 式 (11) と 同じと考えてさしつかえなかろら．

図一8には，上述の抵抗則の有効範囲 が図示されている，図中Ｉは層流理論が 成り立つ範囲, II は, 振動流境界層とし て取り扱うことができる範囲である. 式 (11), (15) が適用しうると推測される範 囲は III の領域である. III の中で，実験

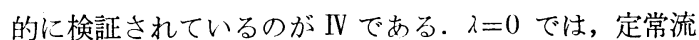
での抵抗則が成り立つことはいうまでもない。これ以外 の領城, 寸なわち, 100 以下の領域，また， $R_{\delta}$ が十分に大きい領域につい ては,今のところ実験，解析ともに十分には行われては

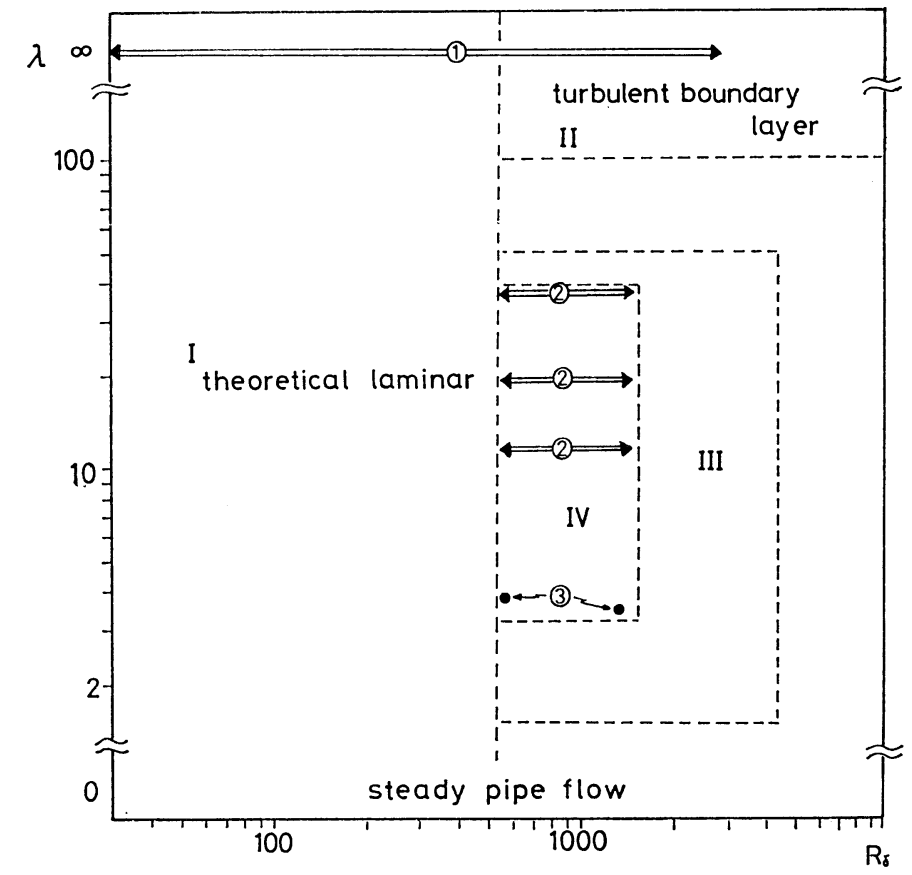

(1) Riedel et al(1972)

(2) Yasukawa.Tagawa(1972)

(3) RUN 9,31 Authors(1975)

I : 層流抵抗則, II : 振動流境界首, III : 今回提案した抵抗則,

IV : IIIの内で実験的に確かめられた領域

(1) Riedel et al., (2) 安川・田川, (3) 著者の実駩

図一8 抵抗則の適用範囲 
いず，今後の成果を待たなければならない。

謝辞：本研究を進めるにあたり，東京工業大学 吉川 秀夫教授をはじめ, 水工研究室の諸氏から有益な助言を いただいた．ここに深く謝意を表します. なお, 本研究 に対し, 著者の一人沢本は, 土木工学科より奨学金を受 けた，記して謝意を表します。

\section{記号}

$C_{e}$ : 抵抗係数 $f$ をあらわす係数, 式 (4).

$C_{\delta}$ : 抵抗係数 $f$ をあらわす係数, 式 (4).

$c_{0}$ : 指数型流速分布形の係数, 式 (13).

$c_{f}:$ 平板境界層の壁面抵抗係数.

$d:$ 管径

$f:$ 振動流の抵抗係数, 式 (3) で定義

$f_{c}:$ 複素抵抗係数

$g:$ 重力の加速度

$J_{0}, J_{1}:$ Bessel 関数

$l:$ 液柱の長さ

$n:$ 流速分布形の指数の逆数

$R_{e}$ : 管径で定義した Reynolds 数 $\frac{\hat{U} d}{\nu}$

$R_{\delta}: \delta$ で定義した Reynolds 数 $\frac{\hat{U} \delta}{\nu}$

$R_{x}:$ Reynolds 数 $\frac{U_{m} x}{\nu}$

$\left[R_{e}\right]$ : 安川・田川(1972)の用いている Reynolds 数

$r:$ 半径方向の距離

$T:$ 振動の周期

$U:$ 管軸方向の流速

$U_{m}:$ 断面平均流速

$U_{0}:$ 境界層外縁での流速

$\hat{U}: U_{m}$ の振幅

$\hat{U}_{*}: U_{\mathrm{amp}}$ の勾配より求めた摩擦速度

$U_{\mathrm{amp}}: U$ の振幅

$V_{c}:$ 複素無次元流速

$V:$ 無次元流速 $\frac{U}{\hat{U}}$

$x:$ 流体粒子の移動距離

$y:$ 壁面からの距離

$\beta_{0}: \sqrt{2} \lambda e^{\frac{3}{4} \pi i}$

$\beta$ : 減衰振動の指数, 式 (18)

$\delta$ : 振動流境界層厚さのパラメータ $\sqrt{\frac{2 \nu}{\omega}}$

$\eta: r / \frac{d}{2}$

$\theta$ : 壁面せん断応力と平均流速の位相差

$\lambda:$ Stokes のパラメータ $\frac{d}{2} / \delta$

$\mu:$ 粘性係数

$\nu:$ 動粘性係数 $\xi:$ 液柱の変位

$\xi_{i}: \xi$ の極大值

$\rho:$ 流体の密度

$\tau_{w}:$ 壁面せん断応力

$\tau_{c}:$ 複素壁面せん断忘力

$\omega$ : 角振動数

$\omega_{0}:$ 液柱の固有振動数 $\sqrt{2 g / l}$

1）日野幹雄・沢本正樹・高須修二 : 円管内振動流の乱流遷 移に関する実験的研究，土木学会論文報告集，第 237 号， 1975.

2) Hino, M., Sawamoto, M. and Takasu, S. : Experiments on transition to turbulence in an oscillatory pipe flow, Jour. Fluid Mech. 75, 193-207, 1976.

3) Kajiura, K. : On the bottom friction in an oscillatory current, Bull. Earthq. Res. Inst., Univ. Tokyo, Vol. 42, 1964.

4) Kajiura, K. : A model of the bottom boundary layer in water wave, Bull. Earthq. Res. Inst., Univ. Tokyo, Vol. 46, 1968.

5) Riedel, H.P., Kamphuis, J.W. and Brebner, A. : Measurement of bed shear stress under waves, Proc. 13 th Coastal Engineering (Vancouver), 1972.

6) Jonsson, I.G. : Measurements in the turbulent wave boundary layer, Proc. 10th IAHR (London), Vol. 1, 1963.

7) Johns, B. : The damping of gravity waves in shallow water by energy dissipation in a turbulent boundary layer, Tellus, Vol. XX, 1968.

8）野田英明：波動による乱流境界層の発達, 第16 四海岸工 学講演会, 1969 .

9）安川 浩・田川昌宏 : 管内自由振動流の減衰性に関する研 究，土木学会論文報告集，第 208 号, 1972.

10）堀川清司・渡辺 晃: 表面波による振動流境界層に関卞る 実験的研究, 第 15 回海岸工学講演会, 1968.

11）堀川清司・水口 優：振動流境界層に関する実験, 第 20 回海岸工学講演会, 1973.

12) Eagleson, P.S. : Laminar damping of oscillatory waves, Proc. ASCE, Vol. 88, No. HY 3, 1962.

13）岩垣雄一・土屋義人・坂井順行 : 海底摩擦による波高減 衰に関する基礎的研究 (2), 第 11 回海岸工学講演会, 1964.

14）松梨順三郎・川谷 健：波による海底変形に関する基礎的 研究, 第 12 回海岸工学講演会, 1965.

15）土木学会編：水理公式集, 1971 .

16）日本機械学会編：機械工学便覽，1961.

17）石原藤次郎・本間仁編：応用水理学 中一II, 丸善, 1966.

18）荻原能男: 利水管路の流量変動にともなう水理学的問題 の研究, 東京工業大学, 学位論文, 1973.

19）沢本正樹：円管内振動乱流の流速分布 および エネルギー 過程, 東京工業大学土木工学科研究報告 No. 19, 1975.

20) Hinze, J.O. : Turbulence, McGraw-Hill, 1959.

21) Daily, J.W. and Harleman, D.R.F. : Fluid Dynamics, Addison- Wesley, 1966.

22) Von Kerczek, C. and Davis, S.H. : Linear stability theory of oscillatory Stokes layers, Jour. Fluid Mech., 62, 753, 1974.

23) Patel, V.C. and Head, M.R. : Reversion of turbulent to laminar flow, Jour. Fluid Mech., 34, 371, 1968.

(1976.5.24 • 受付) 